\title{
EFFECT OF GOOD CORPORATE GOVERNANCE PRACTICES TOWARD THE MOSQUE ACCOUNTING APPLICATION SURVEY OF MOSQUE IN BOGOR
}

\author{
Retno Martanti Endah Lestari ${ }^{\left.a^{*}\right)}$, Agung Fajar Ilmiyono ${ }^{a)}$, Djalaludin Al Mahali ${ }^{a)}$ \\ ${ }^{a)}$ Pakuan University, Bogor, Indonesia \\ ${ }^{*}$ Corresponding Author: retno.martanti@unpak.ac.id
}

Article history: received 15 June 2019; revised 15 July 2019; accepted 26 August 2019

\begin{abstract}
This research was designed, one of which is to provide input to the Ministry of Religion and DKM in particular that mosque financial management must be transparent and accountable by applying the mosque accounting application in its implementation so that the targeted financial management of mosque governance can be easily achieved. In reality, as many as 30 mosques were selected in Bogor, that the effect of GCG application on the application of mosques in 30 selected mosques, which involved the principles of accountability, transparency, responsibility, independence and the principle of reasonableness had no influence on the process of applying the mosque application, this is certainly a lack of knowledge the mosque DKM how important is the implementation of good corporate governance. The purpose of this study is to determine the economic characteristics of the area in mosques in the Bogor area and whether the application of good corporate governance can affect the application of mosque accounting applications. This type of research is verification with an explanatory survey. Data collection method using a questionnaire. Data collection techniques from primary data and secondary data. Sampling using a purposive sampling method as many as 30 mosques in the Bogor Region. It can be concluded that the economic characteristics of the area at the 30th Mosque selected, still not evenly distributed, this can be seen from the different educational backgrounds of the DKM Mosque and the different area of the mosque and the results of the research data test application of good corporate governance has no influence on the application Mosque Accounting Application.
\end{abstract}

Keywords: mosque accounting application; good corporate governance

\section{INTRODUCTION}

Transparency and Accountability, are important because of the problem of Good Corporate Governance (GCG). GCG is one of the keys to a company's success to grow and be profitable in the long run, while winning global business. But in its implementation, GCG faces many fairly complex obstacles, one of the important problems that is the cause is the lack of accountability and transparency, all activities of institutions both public and private are always demanded to be transparent and accountable.

Nonprofit organizations are the absence of ownership as is usual in business entities, in the sense that ownership in nonprofit entities cannot be sold, transferred or redeemed, or the ownership does not reflect the proportion of resource sharing of nonprofit entities at the time of liquidation or liquidation of nonprofit entities can also be sources Entity power comes from donors who do not expect repayments or economic benefits that are proportional to the amount of resources provided. Religious organizations are an example of a non-profit organization that is considered special from other non-profit organizations. Specificity can be seen in terms of implementation.

According to the book Accounting for NGOs and Political Parties (216-217) states that in terms of its implementation, a religious organization is run by an institution or organization that emerges in the awareness of the vision and mission of the religion. Religious organizations refer to organizations in the form of places of worship such as mosques, churches, pure, monasteries, and organizations formed as places of religious study such as pesantren, and other organizations engaged in the religious field. Resources or managers involved in managing religious organizations are not professional people as in business organizations.

The practice of accounting as an instrument of accountability in religious entities, especially Islam through mosques, is still rarely of particular concern. Whereas in the framework of applying the principle of accountability to the community, management of an organizational entity must carry out financial management, including the publication and accountability of financial statements. Another problem that often arises is that there are still many mosques that do not record in detail cash income and expenditure, usually only recorded limited to cash receipts and disbursements without specifying the source of cash income and the use of mosque cash for anything. The recording of a mosque's finances usually only includes the receipt and disbursement of the mosque's cash without showing the amount of assets owned by the mosque and its value, so many cases of loss of mosque assets due to weaknesses in the system of recording financial statements.

It is time, the mosque is not only a place of worship, but more than that a gathering place or a place to exchange ideas, even as a supporter of economic activities of the people. 


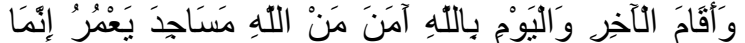

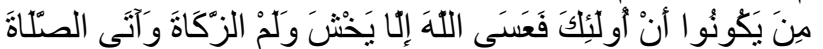 الَمُهُنَدِينَ}

Truly, those who prosper in the Mosques of Allah are those who believe in Allah and the hereafter, establish prayer, perform Zakat and not be afraid except only to Allah. They must be from the group of people who are guided by Allah. " (QS. At-Taubah [9] : 18)

Definition of Good Corporate Governance is a system that regulates and controls companies to create added value for all stakeholders, Adrian Sutedi in his book Good Corporate Governance [1]. There are two things that are emphasized in this concept. First, the importance of the right of shareholders to obtain information correctly (accurately) and on time and secondly, the company's obligation to make disclosure (disclosure) accurately, timely, and transparent to all information on company performance, ownership and stakeholders. The same thing is defined by the OECD in John Pieris and Nizam Jim [2]. Corporate governance is the system by which business corporations are directed and controlled. The corporate governance structure specifies the distribution of right and responsibilities among different participants in the corporation, such as the board, the managers, shareholders and other stakeholders, and spell put the rules and procedur for making decisions on corporate affairs.

1.At present there are 785 mosques in the city of Bogor scattered, from sources quoted from simas.kemenag.go.id, we can imagine the potential funds that must be managed by DKM, how complicated is the recording of incoming and outgoing money if in terms of financial management it does not use Mosque accounting application in accordance with PSAK 45. Good Corporate Governance is one of the non-financial components that is currently an important issue and needs to be considered by profit and or non-profit organizations. Good Corporate Governance is a governance of the mosque that applies the principles of transparency, accountability, responsibility, independence and fairness.

2.There are many people as contributors to mosque funding sources, there is an antipathy towards the management of mosque funds, this happens because the mosque management is not transparent in providing mosque financial reporting and its management is not good causing many mosque worshipers to come out, so that people begin to hesitate in giving funds to Mosques, another problem that arises there is a gap in the availability of funds between one mosque with limited funds and another mosque with the availability of excess funds, so that mosque administrators with limited funds will be helplessly looking for funds. This is certainly not a good image, that the mosque must seek funding, then the implementation of good governance / GCG of the mosque with the mosque's accounting application will respond to public distrust of the management of mosque funds and between mosques can help one another in the availability of funds.

\section{Practice Good Corporate Governance}

Another GCG concept study conducted by Bahrudin [3] examines the accountability of transparency in financial management of the Darul Hidayah Mosque in Airkuning village, Jembarana Subdistrict. The results of the funding source come from compulsory contributions from pilgrims, infaq and alms pilgrims, and government assistance, the Darul Hidayah Mosque construction committee. have implemented accountability in financial management by putting forward the mandate attitude both vertically (God) and horizontally (Jamaah), the transparency process at the Darul Hidayah Mosque was still less than optimal because the committee conveyed the income of funds and the use of funds only through word of mouth. In 2018, Maria and Cherrya conducted this research discussing the application of good corporate governance (GCG) in nonprofit and profit oriented organizations, namely the St. Peter's Catholic Church and Bank Central Asia Tbk. This research is a qualitative research. Data collection techniques using observation, interviews, and documentation. The results of this study indicate that the first application of good corporate governance (GCG) applied by the St. Peter's Catholic Church is transparency, accountability, responsibility, as well as fairness and equality. But the principle of independence has not been well implemented. Second, the implementation of good corporate governance (GCG) at Bank Central Asia Tbk has implemented the five principles well. Third, the difference in the implementation of good corporate governance (GCG) between the St. Peter Parish Catholic Church and Bank Central Asia Tbk lies in the five principles namely, transparency, accountability, responsibility, independence, as well as fairness and equality.

\section{Application of Mosque Accounting}

Referring to the background in this study, there are a number of scientific articles relating to research on the key success factors of the GCG concept in accounting for mosques in various regions of Indonesia used as a reference in this study. Research conducted by Endang [4] Application of Accountability and Transparency of Financial Management of the Jamik An-Nur Mosque with the results of the Accountability research at the Jamik An-Nur Sekayu Mosque namely, in terms of legal accountability and honesty the absence of official regulations only refers to the legal rules of organizational habits through meetings or management meetings with an unspecified period of time. The accountability of the program at the Jamik An-Nur Sekayu Mosque is the commitment of the mosque management to realize the vision and mission as guidelines for the management of the mosque. The accountability of the process at the Jamik An-Nur mosque now is not a match between the realization of the activities and the initial plan, so it is difficult to measure success and failure in achieving the goals and objectives set. Policy accountability at the Jamik AnNur Sekayu Mosque, namely, the policy regarding the accountability of mosque caretakers is only done verbally, but there is still agreement and consideration of all management and data are not documented so that sometimes 
the application is inconsistent. However, the administrator of the Masjid Jamik An-Nur has tried to convey its accountability to the public, even though the level of accountability is lacking. Transparency carried out by the administrator of the Jamik An-Nur Sekayu Mosque, among others, provides convenience to outsiders who need information about the results mosque's financial performance.

Submission of financial statement information is done in writing and is conveyed through the media of information directly after every Friday prayer. The management has recorded financials at the Jamik An-Nur Sekayu Mosque as proof of the mosque's cash flow and also as evidence of the management's performance in accountability for the mandate given. With a good record, it is expected that all worshipers can understand the notes made and avoid negative things that might occur. The management used by the management of the Jamik AnNur mosque is to record cash inflows and cash outflows then added to produce a balance. Although the recording is still simple, but it can run well and has never found a problem, but in practice the management remains responsible (accountability) with what is done and open (transparency) in terms of recording and reporting.

\section{Framework for Thinking}

Research conducted by Intan [5] Analysis of Accountability Practices and Transparency Forms in Mosque Organizations (Case Study at Masjid Raya Darul Amal Salatiga) This study aims to describe the practice of accountability and transparency in mosque organizations. Accountability practices are divided into 5 parts, namely, legal accountability and honesty, program accountability, process accountability, policy accountability and financial accountability. This research was conducted by the case study method in the Great Mosque of Darul Amal Salatiga involving qualitative data. The Great Mosque of Darul Amal is the largest mosque in the Salatiga region. The results of this study indicate that accountability practices and forms of transparency in the Darul Amal Grand Mosque Organization are inadequate.

\section{RESEARCH METHODS}

This type of research is a verification study with the Explanatory Survey method that aims to test hypotheses, which are generally studies that explain phenomena in the form of relationships between variables (2 or more variables).

Data collection methods, the authors do using a questionnaire. Data collection techniques, the authors do from primary data and secondary data. The type of data used is quantitative data which is primary data obtained through questionnaires in the form of respondents' answers to the question items contained in the research instrument. by using a Likert scale, that is, a score of 5 (SS = Strongly Agree), a score of $4(\mathrm{~S}=$ Agree $)$, a score of $3(\mathrm{~N}=$ Neutral $)$, a score of $2(\mathrm{TS}=$ Disagree $)$, a score of $1(\mathrm{STS}=$ Strongly Agree $)$.
Taking respondents as samples in this study were conducted by the DKM management. Sampling using stratified sampling method, namely the method of taking respondents by grouping by region. The number of samples taken was 30 mosques from 92 populations spread across the Bogor area. This analysis is a quantitative analysis because the data used are primary data which is a technique carried out by means of a survey that is interviewing and distributing questionnaires to reveal the behavior of research variables. which states the respondent's personal data, obtained from respondents' answers through questionnaires. Then the data obtained from respondents' answers to the questions asked, then the percentage is calculated. Data collection methods, the authors do using a questionnaire. Data collection techniques, the authors do from primary data and secondary data. Primary data is data obtained directly sourced from answers to questionnaires from respondents sent directly to the DKM Mosque in the Bogor area by involving students in the process of dissemination, interviews and collection. Whereas secondary data was obtained from various literatures, books and related journals. Taking respondents as samples in this study were conducted at the Mosques in the Bogor area.

\section{RESULTS AND DISCUSSION}

\section{Description of Respondents}

The description of the respondents in this study was a description / condition or characteristics of the respondents who were sampled, namely the Mosque in the Bogor area. The sample descriptions include age, education, experience, age of the mosque building, mosque area, source of income, and their ability to manage their finances

Age

The number and percentage of respondents by age group can be seen in the Table 1 .

Table 1 Characteristics of Mosque DKM based on Age 2018

\begin{tabular}{|c|c|c|}
\hline Age Range (years) & Amount (Mosque) & Frequency \\
\hline $21-30$ & 7 & $23 \%$ \\
\hline $31-40$ & 10 & $33 \%$ \\
\hline $41-50$ & 5 & $17 \%$ \\
\hline $51-60$ & 5 & $17 \%$ \\
\hline $61-70$ & 3 & $10 \%$ \\
\hline Total & 30 & $100 \%$ \\
\hline
\end{tabular}

(source: primary data processed by the author)

\section{Education}

The number and percentage of respondents based on their level of education can be seen in Table 2 .

Table 2.Characteristics of DKM Mosque on Education 2018

\begin{tabular}{|c|c|c|}
\hline Education & Amount (Mosque) & Frequency \\
\hline S2 & 6 & $20 \%$ \\
\hline S1 & 14 & $47 \%$ \\
\hline SMA & 10 & $33 \%$ \\
\hline Total & 30 & $100 \%$ \\
\hline
\end{tabular}

(source: primary data processed by the author) 
Based on table 2 it can be seen that the level of education of respondents is formal education taken by each sample to get a diploma. Characteristics of the sample based on education can be seen that as many as 6 people or $20 \%$ have S2 education, then as many as 14 people or $33 \%$ have $\mathrm{S} 1$ education, as many as 10 people or $20 \%$ have high school education.

\section{Experience}

The number and percentage of respondents based on the duration of doing business can be seen in Table 3 below:

Table 3 Characteristics of DKM Mosque on Experience 2018

\begin{tabular}{|c|c|c|}
\hline Experience (years) & Number of people) & Frequency \\
\hline $1-5$ & 18 & $60 \%$ \\
\hline $6-10$ & 7 & $23 \%$ \\
\hline $11-15$ & 2 & $7 \%$ \\
\hline $16-20$ & 3 & $10 \%$ \\
\hline Total & 30 & $100 \%$ \\
\hline
\end{tabular}

(source: primary data processed by the author)

The experience of being a caretaker / DKM of the Mosque is the length of time the respondents carry out their duties as DKM of the Mosque. Based on table 3 it can be seen that the number of respondents as many as 18 people or $60 \%$ have $1-5$ years experience, as many as 7 people or $23 \%$ have 6-10 years experience, as many as 2 people or $7 \%$ have 11-15 experience years and as many as 3 people or $10 \%$ have 16-20 years experience.

\section{Age of the Mosque}

The chosen mosque has an average mosque age above 10 years, in the sense that the mosque has long been built and used for worship activities.

\section{Mosque Building Area}

The number and percentage of respondents based on mosque building area can be seen in Table 4 .

Table 4.Mosque Characteristics based on Building Size 2018

\begin{tabular}{|c|c|c|}
\hline Building Size (meters) & Amount (Mosque) & Frequency \\
\hline $72-458$ & 10 & $33 \%$ \\
\hline $459-845$ & 5 & $17 \%$ \\
\hline $846-1232$ & 9 & $30 \%$ \\
\hline $1233-1619$ & 4 & $13 \%$ \\
\hline $1620-2006$ & 2 & $7 \%$ \\
\hline Total & 30 & $100 \%$ \\
\hline
\end{tabular}

(source: primary data processed by the author)

The mosque in the city of Bogor, Alhamdulillah is in the area of 72 - 458 meters as many as 10 mosques or $33 \%$, an area of $459-845$ meters as many as 5 mosques or $17 \%$, has an area of 846-1232 meters as many as 9 mosques or $30 \%$, has an area of 1233-1619 meters as many as 4 mosques or $13 \%$, and as many as 2 mosques or $7 \%$ have a mosque area of 1620-2006 meters.

\section{Revenue}

The number and percentage of respondents based on mosque income can be seen in Table 5
Table 5. Characteristics of Mosques based on Income 2018

\begin{tabular}{|c|c|c|}
\hline Revenue (Rp) & Amount (Mosque) & Frequency \\
\hline $490.000-15.500 .000$ & 19 & $63 \%$ \\
\hline $15.600 .000-35.000 .000$ & 8 & $27 \%$ \\
\hline $35.100 .000-50.000 .000$ & 2 & $7 \%$ \\
\hline $50.100 .000-75.000 .000$ & 1 & $3 \%$ \\
\hline Total & 30 & $100 \%$ \\
\hline
\end{tabular}

(source: primary data processed by the author)

Mosque income in the city of Bogor in 30 mosques selected based on table 5 can be seen that the number of respondents as many as 19 mosques or $63 \%$ have income ranging from Rp.490,000-Rp15,500,000, 8 mosques or $27 \%$ have income ranging from Rp15,600,000- Rp. 35,000,000, 2 Mosques or $7 \%$ have income ranging from Rp. 35,100,000Rp. $50,000,000$, and there are 1 Mosque or $3 \%$ have income ranging from Rp. 50,000,75,000.

Whereas based on the number of mosque worshipers, 13 mosques or $43 \%$ of mosque worshipers range from 30 175 people, while as many as 6 mosques or $20 \%$ mosques they are in the range of $176-321$ people, as many as 2 mosques or $7 \%$ the number of worshipers are at 322-467 worshipers, as many as 3 mosques or $10 \%$ with the number of worshipers in the range 468-613, and there are 6 mosques in the range of 614-759 worshipers or $20 \%$. The details are presented in Table 6.

Table 6 Mosque Characteristics based on the Number of Mosque Congregations 2018

\begin{tabular}{|c|c|c|}
\hline Number of pilgrims & Amount (Mosque) & Frekuensi \\
\hline $30-175$ & 13 & $43 \%$ \\
\hline $176-321$ & 6 & $20 \%$ \\
\hline $322-467$ & 2 & $7 \%$ \\
\hline $468-613$ & 3 & $10 \%$ \\
\hline $614-759$ & 6 & $20 \%$ \\
\hline Total & 30 & $100 \%$ \\
\hline
\end{tabular}

(source: primary data processed by the author)

The last respondent data on 30 selected mosques included the level of understanding of the understanding of the mosque's DKM on mosque governance, 30 selected mosques answered quite understand on this question.

\section{Normality Test Results}

Based on the results of the normality test that the significance value (Asymp. Sig. 2- tailed) obtained that is equal to 0.200 exceeds 0.05 , it can be concluded that the data is normally distributed.

\section{Multicollinity Test Results}

Based on Multicollinity Test Results that the VIF values of X1, X2, X3, X4 and X5 were 2,048, 1,534, 1,673, 1,704 , and 1,425 the VIF value of the independent variable was more than 0.1 thus it can be concluded that the regression model did not find any multicollinity problems among the independent variables.

\section{Heterokedacity Test Results}

Based on the results of scatterplot diagrams, data are scattered randomly without forming a specific pattern, and the points spread above and below 0 on the $\mathrm{Y}$ axis, this proves there is no heterokedacity. Thus it can be concluded 
that in this regression model there are differences in the variance of the residuals from one observation to another.

\section{Multiple Linear Regression Test Results}

Based on the results of the Multiple Linear Regression Test when viewed in the Unstandardized Coefficients column column $\mathrm{B}$, the equation of the multiple linear regression analysis is as follows:

$$
Y=22,271+-0,342 X_{1}+0,720 X_{2}+0,261 X_{3}+-0,596 X_{4}+0,290 X_{5}
$$

In the regression equation above the constant is 24,054 , this means that if there is no change in the variable GCG (X) that affects, then the mosque application that occurs in the mosque in the city of Bogor is 24,054. While the results of multiple regression tests for independent variables can be explained as follows:

1. Transparency GCG coefficient value (X1) of 0.334 negative effect on the application of the mosque (Y). This implies that every GCG increase in one unit then the mosque application variable decreases by $-0,342$.

2. The value of the GCG Accountability coefficient (X2) of 0.720 has a positive effect on the application of the mosque (Y). this implies that every GCG increase in one unit then the mosque application variable increases by 0.720 .

3 . The value of the GCG Responsibility coefficient (X3) of 0.261 has a positive effect on the application of the mosque (Y). this implies that every GCG increase in one unit then the mosque application variable increases by 0.261 .

4. The value of the GCG coefficient of Independence (X4) of -0.596 has a negative effect on the application of the mosque (Y). this implies that for every increase in GCG of one unit, the mosque application variable decreases by 0,342 .

5. Fairness GCG coefficient (X5) of 0.290 has a positive effect on mosque applications $(\mathrm{Y})$. this implies that every increase in GCG is one unit, the mosque application variable increases by 0.290 .

\section{Determination Coefficient Test Results (R2)}

Based on the table above the determination coefficient test results (R2), showing that the value of $\mathrm{R}$ square obtained by 0.170 or $17 \%$ this shows that the application of the mosque in the chosen mosque in Bogor city is influenced by variables $\mathrm{X} 1, \mathrm{X} 2, \mathrm{X} 3, \mathrm{X} 4, \mathrm{X} 5$ of $17 \%$ and the rest are influenced by other variables not examined in this study.

\section{Hypothesis Testing}

\section{Test Results $t$}

Based on the results of the test:

1. GCG Variable Transparency X1 has a calculated value of -0.326 with a significance level of 0.747 which is greater than the error rate (a) of $5 \%$ or 0.05 so that it can be concluded that $\mathrm{X} 1$ has no significant effect on mosque applications.

2. GCG Variable Accountability X2 has a calculated value of 1.608 with a significant level of 0.121 which is greater than the error rate (a) of $5 \%$ or as large as 0.05 so that it can be concluded that $\mathrm{X} 2$ has no significant effect on mosque applications.
3. GCG Variable Liability X3 has a calculated value of 0.333 with a significance level of 0.742 which is greater than the error rate (a) of $5 \%$ or 0.05 so that it can be concluded that X3 has no significant effect on mosque applications.

4. GCG Variable Independence X4 has a calculated value of -1.184 with a significant level of 0.248 which is greater than the error rate (a) of $5 \%$ or 0.05 so it can be concluded that $\mathrm{X} 4$ has no significant effect on mosque applications.

5. Fairness GCG Variable X5 has a calculated value of 0.223 with a significant level of 0.826 which is greater than the error rate (a) of $5 \%$ or as large as 0.05 so that it can be concluded that $\mathrm{X} 4$ has no significant effect on mosque applications.

\section{Test Results F}

Based on the results of the $\mathrm{F}$ test shows that the results of the regression calculation with an $\mathrm{F}$-count value of 0.981 with a significant level of 0.449 which means that overall the variables $\mathrm{X} 1, \mathrm{X} 2, \mathrm{X} 3, \mathrm{X} 4$, and $\mathrm{X} 5$ together (simultaneously) do not significantly influence the application The mosque.

The Influence of Transparency Principles on the Application of Masjid Accounting in the Selected Mosque of Bogor City.

Based on the partial test that has been carried out between GCG Transparency (X1) on the Mosque Accounting Application (Y). Hypothesis testing results for the calculated t-value for the Transparency variable has a tcalculated value of -0.332 with a significant level of 0.747 which is greater than the error rate (a) of $5 \%$ or 0.05 so it can be concluded that the transparency principle has no significant effect on the Application of Mosque Accounting at selected mosques in Bogor City.

The Influence of the Accountability Principle Against the Application of Masjid Accounting in the Selected Mosque of Bogor City.

Based on the partial test that has been done between GCG Accountability (X2) of the Mosque Accounting Application (Y), the hypothesis test results show the t-count value for the Accountability variable has a t-count value of 1.608 with a significant level of 0.747 which is greater than the error rate (a) by $5 \%$ or by 0.05 so it can be concluded that GCG Accountability significantly does not affect the Accounting Application of the Mosque in the chosen mosque in Bogor City.

The Influence of the Principle of Responsibility on the Accounting Application of the Mosque in Bogor's Selected Mosque.

Based on the partial test that has been done between GCG Accountability (X3) on the Accounting Application of the Mosque (Y), the hypothesis testing results of the t-count value for the Responsibility variable has a t-value of 0.333 with a significant level of 0.747 which is greater than the error rate (a ) by $5 \%$ or by 0.05 so it can be concluded that the GCG responsibility does not significantly affect the 
Accounting Application of the Mosque in the chosen mosque in Bogor City.

Influence of the Principle of Independence on the Application of Masjid Accounting in the Selected Mosque of Bogor City.

Based on the partial test that has been done between the GCG Independence (X4) against the Mosque Accounting Application (Y), the hypothesis testing results of the calculated t-value for the independence variable has a $\mathrm{t}$ calculated value of -1.184 with a significant level of 0.248 which is greater than the error rate (a) by $5 \%$ or by 0.05 so it can be concluded that GCG independence does not significantly affect the Accounting Application of the Mosque in the chosen mosque in Bogor City.

Influence of the Principle of Fairness Against the Application of Masjid Accounting on the Chosen Mosque of Bogor City.

Based on the partial test that has been done between the GCG of Fairness (X5) on the Accounting Application of the Mosque (Y), the results of hypothesis testing of the tcount value for the reasonableness variable have a t-value of 0.223 with a significant level of 0.826 which is greater than the error rate (a ) by $5 \%$ or equal to 0.05 so that it can be concluded that the fairness of GCG has no significant effect on the Accounting Application of Mosques in selected mosques in Bogor City.

The principles of mosque financial management which are expected to occur in the future are illustrated below:

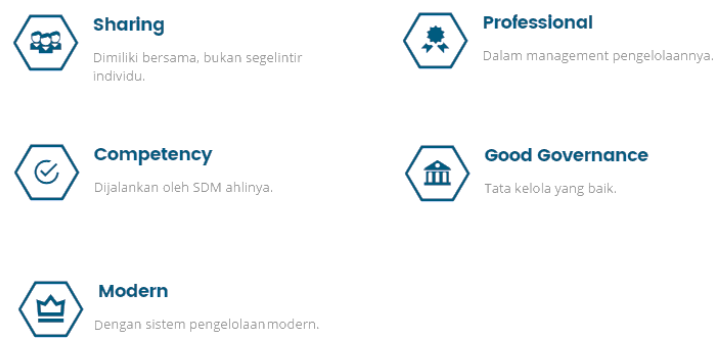

Figure 1. The principles of mosque financial management which are expected to occur in the future

\section{CONCLUSION}

Based on the results of research and testing of the data above, the author tries to conclude the following below:

1. Identification of the economic characteristics of the area in the 30 selected mosques, it is still not evenly distributed. This can be seen from the different educational backgrounds of the DKM Mosque and the different area of the mosque.

2. Identification of the characteristics of Mosque Funds found in Bogor in 30 selected mosques, it is still very uneven that each mosque experiences very different funds entry inequality.

3. Effect of GCG Application on the Application of Mosque Applications in 30 selected Mosques, the results of the research data test did not have an influence on the application process of the Mosque.

4. Improving the management of a good mosque with the Mosque Accounting Application in Bogor, with the results of this study this is expected to be achieved, especially at 30 selected mosques.

5. Increasing public trust and more equitable utilization of mosque funds, has not yet been achieved. This is because there is no system that is able to see which mosque has large funds and which mosques lack funds.

\section{Suggestion}

1.Identification of the economic characteristics of the area in the 30 selected mosque, using the Mosque Accounting Application, the mosque economy can help each other in terms of expansion of the mosque building

2. Identification of the characteristics of Mosque Funds found in Bogor in 30 selected Mosques, with the use of the Mosque Application, the community, Ministry of Religion, Baznas, and Waqf Board can find out how much the source of funds for the Mosque in the city of Bogor.

3. Effect of GCG Application on the Application of Mosque Applications in 30 selected Mosques, that the principles of accountability, transparency, responsibility, independence and fairness principle have no influence on the process of implementing the mosque application, this is certainly a lack of knowledge of the Mosque DKM how important the application of GCG is.

4. Improving the management of a good mosque with a mosque accounting application in Bogor, so that the chosen mosque can apply the mosque accounting application and be able to give an example to other mosques in the city of Bogor.

5 . With the use of a mosque accounting application, it can be able to increase public trust and a more equitable utilization of mosque funds. Mosques with large funding sources are able to help mosques with limited funding sources.

6. For the local government, it is hoped to facilitate education and training for the DKM of the Mosque regarding the importance of making and applying financial reports with the mosque's accounting application by implementing GCG principles

\section{Research Limitations}

1.Limited research data, only at 30 mosques in Bogor, so the resulting data is still less than optimal, it is hoped that further research can add more samples.

2. Selected mosques have not been spread evenly over their territory, so they are unable to reflect the economic condition of a mosque equally, the following research might be able to take samples scattered per region in the city of Bogor.

3. Not only analyzing the survey in a descriptive exploratory but more to an explanatory survey, namely analyzing any factors that make indicators of the success of the mosque in managing the funds of the Ummah. 


\section{REFERENCES}

[1] Adrian, Sutedi. 2012. Good Corporate Governance. SinarGrafika. Jakarta.

[2] John Pieris and Nizam Jim Wiryawan. 2007, Business Ethics and Good Corporate Governance, Jakarta, Pelangi Scholar.

[3] Bahrudin, Ni Luh Gd Erni Sulindawati, Made Aristia Prayudi. 2017. Analisis Akuntabilitas Dan Transparansi Pengelolaan Keuangan Pembangunan Masjid Darul Hidayah Desa Airkuning Kecamatan Jembrana Kabupaten Jembrana. e-Journal S1 Ak Universitas Pendidikan Ganesha Jurusan Akuntansi Program S1. Vol: 8 No: 2

[4] Endang, E. 2017. Application of Accountability and Transparency in Financial Management of the AnNur Sekayu Jamik Mosque. ACSY Journal, 6 (1), 41 56.

[5] Intan Pandini, D. 2013. Analysis of Accountability Practices and Transparency Forms in Mosque Organizations (Case Study at the Darul Amal Salatiga Grand Mosque) (Doctoral dissertation, FEBSWCU Accounting Study Program). 